\title{
Alternative substrates in the production of lettuce seedlings and their productivity in the field ${ }^{1}$
}

\author{
Substratos alternativos na produção de mudas de alface e sua produtividade a campo
}

\author{
Gustavo Castoldi²*, Mariângela Brito Freiberger², Laércio Augusto Pivetta², Laerte Gustavo Pivetta² e Márcia \\ de Moraes Echer ${ }^{3}$
}

\begin{abstract}
Based on the hypothesis that alternative substrates should improve the yield of lettuce crops by producing better quality seedlings, the objective of this work was to evaluate the effect of different substrates on the production of seedlings of this species, and their growth in the field. The study was in two stages. The first consisted of the production of lettuce seedlings, and the second assessed their development in the field. Four alternative substrates were tested, obtained by mixing together a sieved vermicompost from which all clumps had been removed, sterilized sand, charred rice husks and basalt powder. The commercial substrate, Plantmax HA ${ }^{\circledR}$, was also tested. In the first phase, which was conducted in a completely randomised design with four replications, the height, root length, number of leaves, leaf area and dry weight of the seedlings were all evaluated 28 days after sowing. In the second phase, which was carried out in the field in a randomised block design with four replications, the plants were harvested 50 days after transplanting and the head diameter, fresh weight, number of leaves and leaf and stem dry weight were evaluated. The alternative substrates produced larger seedlings in less time than the commercial substrate, resulting in a reduction of 10 days in the total crop cycle. The reduction in the time between sowing and harvesting, together with those aspects relating to sustainability, are the main advantages of the use of alternative substrates, since in the field crop production did not differ between treatments.
\end{abstract}

Key words: Lactuca sativa L.. Vermicompost. Carbonized rice husks. Basalt powder.

RESUMO - Baseado na hipótese de que substratos alternativos poderiam melhorar a produtividade da cultura da alface pela produção de mudas de qualidade superior, objetivou-se com este trabalho avaliar o efeito de diferentes substratos na produção de mudas dessa espécie e seu crescimento a campo. O estudo constou de duas etapas: a primeira consistiu da produção de mudas de alface e a segunda avaliou o desenvolvimento das mesmas a campo. Foram testados quatro substratos alternativos, obtidos a partir da mistura de vermicomposto destorroado e peneirado, areia esterilizada, casca de arroz carbonizada e pó de basalto, além do substrato comercial Plantmax $\mathrm{HA}^{\circledR}$. Na primeira etapa, conduzida em delineamento inteiramente casualizado e com quatro repetições, avaliou-se, 28 dias após a semeadura, altura, comprimento da raiz, número de folhas, área foliar e massa de matéria seca das mudas. Na etapa de campo, conduzida em delineamento de blocos ao acaso e com quatro repetições, as plantas foram colhidas 50 dias após o transplantio e foram avaliados diâmetro da cabeça, massa de matéria fresca, número de folhas e massa de matéria seca das folhas e do caule. Os substratos alternativos produziram mudas maiores e em menor tempo do que o substrato comercial, o que conferiu redução de 10 dias no ciclo total da cultura. A redução do período entre semeadura e colheita, aliada a aspectos relacionados à sustentabilidade, conferem a principal vantagem do uso dos substratos alternativos, uma vez que no campo a produtividade da cultura da alface não diferiu entre os tratamentos.

Palavras-chave: Lactuca sativa L.. Vermicomposto. Casca de arroz carbonizada. Pó de basalto.

\footnotetext{
*Autor para correspondência

${ }^{1}$ Recebido para publicação em 28/09/2010; aprovado em 02/12/2013

Pesquisa financiada pela Universidade Estadual do Oeste do Paraná

${ }^{2}$ Programa de Pós-Graduação em Agronomia/Agricultura, Fazenda Experimental Lageado, Faculdade de Ciências Agronômicas, FCA/UNESP, Rua José Barbosa de Barros, 1780, Botucatu-SP, Brasil, 18.610-307, Brasil, castoldi@fca.unesp.br, mariangelabf@fca.unesp.br, laerciopivetta@fca. unesp.br; lgpivetta@fca.unesp.br

${ }^{3}$ Departamento de Produção Vegetal/CCA/UNIOESTE, Marechal Cândido Rondon-PR, Brasil, mmecher@bol.com.br
} 


\section{INTRODUCTION}

The lettuce (Lactuca sativa L.) is an annual herbaceous vegetable of the Asteraceae family, and represents an important source of mineral salts, mainly calcium and vitamins (FILGUEIRA, 2003), being one of the most cultivated and consumed vegetable crops in Brazil. This is due to several factors, such as its adaptability to varied climatic conditions, the possibility of successive crops in the same year, the low cost of production and a low susceptibility to pests and disease (MEDEIROS et al., 2007).

To produce lettuce with good acceptance in the market, the planting of healthy and vigorous seedlings is of paramount importance. Thus, the production of seedlings can be considered as one of the most important stages in the cultivation of lettuce, since depending on this are the productive performance of the plants, the quality of the product destined for the consumer market and the profits of the producer (MINAMI, 1995; SOUZA et al., 2008).

In the production of vegetable seedlings the use of trays and substrates is common, facilitating handling and enabling greater health and nutritional control. A substrate for the production of seedlings has the purpose of ensuring quality plant growth in a short time and at low cost (FILGUEIRA, 2003). Silva Júnior and Visconti (1991) describe how a good substrate should have the ability to retain nutrients and water, good aeration, low resistance to root penetration and good resistance to loss of the structure of the root ball, which is essential for success when transplanting.

Substantial increases in productivity, achieved in production systems of vegetable seedlings, are largely due to the use of substrates (SMIDERLE et al., 2001). In this context, the formulation of substrates by the farmer can be very advantageous (MENEZES JÚNIOR;FERNANDES, 1998). However, the formulation of an alternative substrate which would be more sustainable from a socio-economic and environmental view point, is dependent on the availability of quality material for its composition, this characteristic varying with the region. A good alternative is to use regional substrates that can be easily obtained (CARNEIRO JÚNIOR; SENO;FERREIRA FILHO, 2000).

Based on the hypothesis that alternative substrates could improve the productivity of lettuce crops by producing superior-quality seedlings, the aim of this work was to evaluate different substrates in the production of lettuce seedlings and the growth of these plants in the field.

\section{MATERIAL AND METHODS}

The study was carried out between March and June, 2008, and consisted of two stages. The first dealt with the production of lettuce seedlings using alternative substrates, and the second assessed their development in the field. Both stages were carried out in an area belonging to the Centre for Experimental Stations of West Paraná State University, in the town of Marechal Cândido Rondon, Paraná, Brazil, situated at 54 $01^{\circ}$ ' $45^{\prime \prime}$ W and $24^{\circ} 31^{\prime} 42^{\prime \prime} \mathrm{S}$ and an average altitude of 420 metres.

The treatments consisted of four alternative substrates and the commercial substrate Plantmax HA ${ }^{\circledR}$ (composed of composted pine bark, peat, charcoal and vermiculite), suitable for the production of vegetable seedlings. The alternative substrates were obtained from mixing together a sieved vermicompost from which all the clumps had been removed, sterilized sand, charred rice husks and basalt powder, in the following proportions: T1 (100\% vermicompost), T2 (50\% vermicompost, $25 \%$ rice husks, $15 \%$ basalt powder and $10 \%$ sand), T3 (60\% vermicompost, $15 \%$ rice husks, $15 \%$ basalt powder, $10 \%$ sand), T4 (60\% vermicompost, $15 \%$ rice husks, $10 \%$ basalt powder, 15\% sand) and T5 (Plantmax $\left.\mathrm{HA}^{\circledR}\right)$.

The substrates were characterised physically by wet and dry density analysis, following the Hoffmann method (1970), as described by Backes (1988), and by particle-size distribution, using sieves of 4.0, 2.0, 1, 0, 0.5, 0.25 and 0.125 $\mathrm{mm}$, in accordance with De Bootd and Verdonck (1972) (Tables 1 and 2). The chemical analysis of the vermicompost (Table 3) - principal constituent of the alternative substrates and produced from cattle manure - was carried out according to the methodology described in Raij and Quaggio (1983).

For production of the seedlings, seeds of "mimosa" lettuce cv. Faloêz Roxane were used. These were sown on 25 March 2008, in polystyrene trays, each with 200 cells filled with the different substrates. When sowing, one seed was placed into each cell, giving a total of 100 cells per treatment, so that each experimental unit consisted of 25 plants. Of these

Table 1 - Mean values for wet density and dry density of the substrates

\begin{tabular}{lcc}
\hline \multirow{2}{*}{ Substrate } & Wet Density & Dry Density \\
\cline { 2 - 3 } & ---------------- $\mathrm{g} \mathrm{L}^{-1}$---------------- \\
\hline T1 & 909.08 & 723.94 \\
T2 & 1028.76 & 889.60 \\
T3 & 1069.60 & 909.95 \\
T4 & 1008.79 & 838.97 \\
T5 & 591.78 & 336.11 \\
\hline
\end{tabular}

$\mathrm{T} 1=100 \%$ vermicompost, $\mathrm{T} 2=50 \%$ vermicompost $+25 \%$ charred rice husks $+15 \%$ basalt powder $+10 \%$ sand, $\mathrm{T} 3=60 \%$ vermicompost $+15 \%$ charred rice husks $+15 \%$ basalt powder $+10 \%$ sand, $\mathrm{T} 4=60 \%$ vermicompost $+15 \%$ charred rice husks $+10 \%$ basalt powder $+15 \%$ sand, T5 $=$ Plantmax HA ${ }^{\circledR}$ 
Table 2 - Percentage by weight for particle diameter of the substrates

\begin{tabular}{|c|c|c|c|c|c|c|c|}
\hline \multirow{2}{*}{ Substrate } & \multicolumn{7}{|c|}{ Particle diameter $(\mathrm{mm})$} \\
\hline & $<0.125$ & $0.125-0.25$ & $0.25-0.5$ & $0.5-1.0$ & $1.0-2.0$ & $2.0-4.0$ & $>40$ \\
\hline & 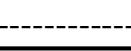 & -1 & $--\%$ & it & - & rer & $-x_{-1}$ \\
\hline $\mathrm{T} 1$ & 6.91 & 8.79 & 19.86 & 27.11 & 27.62 & 9.42 & 0.29 \\
\hline $\mathrm{T} 2$ & 12.53 & 18.27 & 24.46 & 19.83 & 18.79 & 5.76 & 0.36 \\
\hline $\mathrm{T} 3$ & 16.76 & 13.26 & 23.21 & 19.96 & 18.51 & 7.32 & 0.98 \\
\hline $\mathrm{T} 4$ & 12.96 & 11.52 & 27.92 & 22.80 & 19.06 & 5.73 & 0.01 \\
\hline T5 & 0.75 & 0.36 & 13.13 & 48.23 & 13.76 & 18.22 & 5.55 \\
\hline
\end{tabular}

$\mathrm{T} 1=100 \%$ vermicompost, $\mathrm{T} 2=50 \%$ vermicompost $+25 \%$ charred rice husks $+15 \%$ basalt powder $+10 \%$ sand, $\mathrm{T} 3=60 \%$ vermicompost $+15 \%$ charred rice husks $+15 \%$ basalt powder $+10 \%$ sand, $\mathrm{T} 4=60 \%$ vermicompost $+15 \%$ charred rice husks $+10 \%$ basalt powder $+15 \%$ sand, $55=\mathrm{Plantmax}^{\circledR} \mathrm{HA}$

Table 3 - Chemical analysis of the vermicompost

\begin{tabular}{|c|c|c|c|c|c|}
\hline $\mathrm{pH}$ & $\mathrm{P}$ & $\mathrm{Al}^{3+}$ & $\mathrm{K}^{+}$ & $\mathrm{Ca}^{2+}$ & $\mathrm{Mg}^{2+}$ \\
\hline $\mathrm{CaCl}_{2}$ & $\mathrm{mg} \mathrm{dm}^{-3}$ & --.-- & - & 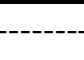 & -- \\
\hline 6.4 & 820.3 & 0.0 & 9.1 & 7.9 & 5.8 \\
\hline
\end{tabular}

$\mathrm{pH}$ in $\mathrm{CaCl}_{2} 0.01 \mathrm{~mol} \mathrm{~L}^{-1}$; Phosphorous extractant: Mehlich-1

plants, four were evaluated during the seedling phase and twelve were used to carry out the field experiment.

During the period between sowing and transplanting, the trays were kept on pallets in a plastic greenhouse (without control of temperature or humidity), the seedlings being watered twice a day with a watering can. At 21 days after sowing (DAS) foliar fertilisation was started, with a foliar fertiliser composed of $15 \% \mathrm{~N}, 15 \% \mathrm{P}_{2} \mathrm{O}_{5}$ and $20 \% \mathrm{~K}_{2} \mathrm{O}$, at a dosage of $3 \mathrm{~g} \mathrm{~L}^{-1}$, being added to the irrigation water.

Evaluation of the seedlings was carried out at 28 DAS. Four seedlings from each replication were removed from the trays and washed in running water to remove the substrate from the roots. The number of leaves was obtained by counting the true leaves, being those with a length of more than $1.0 \mathrm{~cm}$. Root length (root collar to the tip of the main root) and seedling height (root collar to the tip of the highest leaf) were obtained using a ruler. For the other evaluations, the seedlings were separated into root, true leaves and cotyledons with stem.

Leaf area was determined using the Benincasa method (1988). Thus, four leaf discs of known area $\left(0.1735 \mathrm{~cm}^{2}\right)$ were collected from each replication, which corresponded to the subsample leaf-area ( $\left(\mathrm{LA}_{\text {subsample}}\right)$. After drying at $65{ }^{\circ} \mathrm{C}$, the dry weight of the subsample $\left(\mathrm{DW}_{\text {subsample }}\right)$ was determined together with the total leaf dry weight (LDW), with the leaf area (LA) for each replication being obtained from equation 1 :
$\mathrm{LA}=\left[\left(\mathrm{LA}_{\text {subsample }} \mathrm{x} \mathrm{LDW}\right) /\right.$ DWsubsample $]$

To determine dry matter weight, all of the samples (roots, true leaves, leaf discs and cotyledons with stem) were placed separately into paper bags and dried in a forced air flow oven at $65{ }^{\circ} \mathrm{C}$ until reaching constant weight, obtained using a precision balance. Dry weight of the shoots was obtained from the sum of the dry weight of the true leaves, leaf discs and cotyledons with stem.

After evaluation of the seedlings, the field study began. It was established that transplanting of the seedlings would only be done when a seedling presented four true leaves regardless of age. Seedlings grown in substrates T1, T2, T3 and T4 were therefore transplanted at 30 DAS and those from substrate T5 at 40 DAS. Transplanting took place in beds $1.0 \mathrm{~m}$ wide and $0.25 \mathrm{~m}$ high, each experimental unit consisting of 12 plants, spaced $0.30 \mathrm{~m}$ apart with $0.35 \mathrm{~m}$ between rows, with the two central plants being considered usable. The beds were prepared with a rotary hoe, adding $60 \mathrm{~kg} \mathrm{ha}^{-1} \mathrm{~N}, 200 \mathrm{~kg} \mathrm{ha}^{-1} \mathrm{P}_{2} \mathrm{O}_{5}$ and $120 \mathrm{~kg} \mathrm{ha}^{-1}$ of $\mathrm{K}_{2} \mathrm{O}$ during preparation in the form of urea, single superphosphate and potassium chloride respectively.

The total topdressing of $75 \mathrm{~kg} \mathrm{ha}^{-1} \mathrm{~N}$ as urea, was divided up and applied at 14, 24 and 34 days after transplanting, regardless of date. Sprinkler irrigation was carried out daily throughout the crop cycle, in order to maintain the water content of the soil at field capacity. 
Management of weeds, pests and diseases was conducted according to the needs of the crop (FILGUEIRA, 2003). Weed control was by uprooting, with no occurrences of pests or disease being observed.

Plants were harvested 50 days after transplanting. The seedlings from substrates T1, T2, T3 and T4 were therefore harvested on 13 June and those from substrate T5 on 23 June. The productive characteristics of the plants were evaluated. While still in the beds, the average diameter of the lettuce heads was obtained with the aid of a ruler. The usable plants per lot were then cut down and any outer leaves of a yellow coloration or presenting any type of injury were removed. Commercial production was determined by the fresh weight of the shoot (head) of newly-harvested plants and expressed in grams per plant. The plants were separated into leaves and stems, placed into paper bags and dried at $65^{\circ} \mathrm{C}$ until reaching constant weight, in order to obtain the dry matter weight with a precision balance.

For the first stage, the experiment was carried out in a completely randomised design with five treatments and four replications. For the field stage, the design used was of randomised blocks with five treatments and four replications. Data were subjected to variance analysis and means comparison by Tukey test at $5 \%$ probability, using the SISVAR statistical software (FERREIRA, 1999).

\section{RESULTS AND DISCUSSION}

At 28 DAS, the seedlings produced with all the alternative substrates, were larger than those from the commercial substrate (Table 4). Such results demonstrate the effectiveness of alternative substrates in the production of lettuce seedlings. The shorter period the seedlings spend in the nursery translates into lower costs, as well as leaving them less time open to possible mishaps.

Differences were minimal among the alternative substrates. Substrates T1, T2, T3 and T4 proved to be similar for most of the parameters evaluated, differing only in height and dry weight of the seedling shoot, with the highest values for these features being found in seedlings from substrates T1 and T2 (Table 4).

The efficiency of alternative substrates in the production of lettuce seedlings has also been observed by other authors. Leal et al. (2007), evaluating the use of organic compounds as substrates, noted the efficiency of organic compounds produced by a mixture of $66 \%$ sunn hemp (Crotalaria juncea L.) and 33\% Napier grass (Pennisetum purpureum Schum.) in producing lettuce, beet and tomato seedlings. Medeiros et al. (2007), comparing the development of lettuce seedlings in different substrates and under the effects of foliar fertilization with biofertilizers, demonstrated the possibility of producing lettuce seedlings using substrates of organic origin, easily made by the producer. Other alternative substrates such as cattle manure, chicken litter and worm castings were also proved to be effective in the production of lettuce seedlings (SILVA et al., 2008; VIANA; VASCONCELOS, 2008).

In the evaluation of seedlings, the better results obtained with alternative substrates are probably due to the higher nutrient supply, provided mainly by the basalt powder and vermicompost, which is the principle

Table 4 - Number of leaves (NL), length of root (LR), height of seedling (HS), root dry weight (RDW), shoot dry weight (SDW) and leaf area (LA) of lettuce seedlings produced with different substrates

\begin{tabular}{|c|c|c|c|c|c|c|}
\hline \multirow{2}{*}{ Substrate } & \multirow{2}{*}{ NL } & LR & $\mathrm{HS}$ & RDW & SDW & LA \\
\hline & & \multicolumn{2}{|c|}{------------------ cm ----------------- } & \multicolumn{2}{|c|}{------------------ g ------------------- } & $\mathrm{cm}^{2}$ \\
\hline $\mathrm{T} 1$ & $4.25 \mathrm{a}$ & $7.73 \mathrm{a}$ & $6.06 \mathrm{a}$ & $0.05 \mathrm{a}$ & $0.18 \mathrm{a}$ & $76.29 \mathrm{a}$ \\
\hline $\mathrm{T} 2$ & $4.25 \mathrm{a}$ & $6.86 \mathrm{ab}$ & $6.44 \mathrm{a}$ & $0.05 \mathrm{a}$ & $0.18 \mathrm{a}$ & $66.41 \mathrm{a}$ \\
\hline $\mathrm{T} 3$ & $4.13 \mathrm{a}$ & $7.28 \mathrm{a}$ & $5.17 \mathrm{~b}$ & $0.05 \mathrm{a}$ & $0.14 \mathrm{~b}$ & $56.41 \mathrm{a}$ \\
\hline $\mathrm{T} 4$ & $3.88 \mathrm{a}$ & $7.32 \mathrm{a}$ & $4.79 \mathrm{~b}$ & $0.05 \mathrm{a}$ & $0.11 \mathrm{c}$ & 46.92 a \\
\hline $\mathrm{T} 5$ & $2.00 \mathrm{~b}$ & $5.91 \mathrm{~b}$ & $1.63 \mathrm{c}$ & $0.01 \mathrm{~b}$ & $0.01 \mathrm{~d}$ & $2.87 \mathrm{~b}$ \\
\hline MS & 2.968 & 1.803 & 11.737 & 0.001 & 0.015 & 2718.003 \\
\hline $\mathrm{F}$ & $50.294 * *$ & $5.735^{* *}$ & $123.915^{* *}$ & $25.176^{* *}$ & $34.621 * *$ & $6.139 * *$ \\
\hline $\mathrm{CV}(\%)$ & 6.59 & 7.87 & 6.49 & 17.37 & 17.63 & 44.36 \\
\hline
\end{tabular}

Averages followed by the same letters in a column do not differ statistically by Tukey test at $5 \%$ probability. ns - not significant; $*$ significant at $5 \%$; significant at $1 \% ; \mathrm{T} 1=100 \%$ vermicompost, $\mathrm{T} 2=50 \%$ vermicompost $+25 \%$ charred rice husks $+15 \%$ basalt powder $+10 \%$ sand, $\mathrm{T} 3=60 \%$ vermicompost $+15 \%$ charred rice husks $+15 \%$ basalt powder $+10 \%$ sand, $\mathrm{T} 4=60 \%$ vermicompost $+15 \%$ charred rice husks $+10 \%$ basalt powder $+15 \%$ sand, T5 = Plantmax HA ${ }^{\circledR} ;$ MS = Mean square, F = value and significance of the F-test, CV = coefficient of variation 
constituent of these substrates. Vermicompost has been used in the production of seedlings, whether vegetable, fruit or forest, and its efficiency has been demonstrated by several authors (MENEZES JÚNIOR; FERNANDES, 1998; SHUMACHER et al., 2001; SOUZA et al., 2003).

The physical properties of the substrate also directly affect the development of the seedling and the way it's managed, since because the substrate and container are transported and handled, its weight must be taken into account. The density of the substrate, which is directly related to the porosity and the consequent aeration and moisture retention, will therefore influence the cost of shipping, handling and necessary infrastructure (FERNANDES; CORÁ; BRAZ, 2006). Among the substrates studied, the higher density, both wet and dry, of the alternative substrates is noteworthy compared to the commercial substrate (Table 1). Usually, higher densities are associated with lower aeration and water storage; however the magnitude of this effect seems not to have occurred with alternative substrates to the point of harming the growth of the seedlings.

Among the alternative substrates, the variation in density was small, with wet and dry densities lower in substrate T1 (consisting solely of vermicompost). The densities of the substrates T2, T3 and T4 were similar and higher than that of substrate $\mathrm{T} 1$, probably reflecting the addition of rock powder, since the rice husks have a density four times lower than that of the vermicompost (MENEZES JÚNIOR; FERNANDES, 1998), and adding them would probably reduce the density of the substrate. The addition of rock powder to the substrate reduces aeration by filling the spaces with fine particles, changing the geometry of the pore space and affecting the circulation of air and water in the substrate (LEMAIRE, 1995).

Mixing basalt powder and charred rice husks with the vermicompost was done in order to improve its physical and chemical characteristics. The results however, show that vermicompost used alone is capable of producing quality lettuce seedlings as those produced by the addition of basalt powder and rice husks (Table 4). Such a result is important, since, as there is no need to add other materials to the vermicompost, the cost and time spent in preparing the substrate are less.

When evaluating the productive characteristics of the lettuce (Table 5), which was done 50 days after transplanting, a difference was found only in the dry weight of the leaves, which was lower in the lettuce produced with substrate T5 (Plantmax $\mathrm{HA}^{\circledR}$ ). The number, fresh weight and leaf dry weight seen in this study are similar to those reported by Medeiros et al. (2001) for a study with rice husks and worm castings in the production of fertigated lettuce.

In general, the substrates used in producing the seedlings did not affect the productivity of the lettuce in the field (Table 5). This result is probably due to the fact of having adopted a standard size for transplanting the seedling to the field, regardless of the time required to reach this size. In the field, weather conditions, as well as fertilization and crop treatments, ensured uniformity in the growth and productivity of the lettuce. Studying the growth and development of lettuce plants from seedlings kept in polystyrene trays for different periods $(39,46,54$ and 69 days) and transplanted

Table 5 - Head diameter (HD), number of leaves (NL), head fresh weight (HFW), leaf dry weight (LDW) and stem dry weight (DWS ) of lettuce plants grown in the field, from seedlings from different substrates

\begin{tabular}{|c|c|c|c|c|c|}
\hline \multirow{2}{*}{ Substrate } & HD & NL & HFW & LDW & DWS \\
\hline & \multicolumn{2}{|c|}{$\mathrm{cm}$} & ---- & --- g ---- & --------- \\
\hline $\mathrm{T} 1$ & $47.75 \mathrm{a}$ & $29 a$ & $425.25 \mathrm{a}$ & $11.50 \mathrm{a}$ & $1.76 \mathrm{a}$ \\
\hline $\mathrm{T} 2$ & $48.81 \mathrm{a}$ & $28 \mathrm{a}$ & $397.75 \mathrm{a}$ & $10.75 \mathrm{a}$ & $1.58 \mathrm{a}$ \\
\hline $\mathrm{T} 3$ & $48.31 \mathrm{a}$ & $26 \mathrm{a}$ & $376.75 \mathrm{a}$ & $9.75 \mathrm{ab}$ & $1.62 \mathrm{a}$ \\
\hline $\mathrm{T} 4$ & $48.06 \mathrm{a}$ & $26 a$ & $385.75 \mathrm{a}$ & $10.25 \mathrm{ab}$ & $1.56 \mathrm{a}$ \\
\hline $\mathrm{T} 5$ & $48.00 \mathrm{a}$ & $25 \mathrm{a}$ & $297.75 \mathrm{a}$ & $8.02 \mathrm{~b}$ & $1.56 \mathrm{a}$ \\
\hline MS & 0.648 & 9.481 & 9115.2 & 6.925 & 0.029 \\
\hline $\mathrm{F}$ & $0.056^{\mathrm{ns}}$ & $1.735^{\mathrm{ns}}$ & $2.574^{\mathrm{ns}}$ & $6.156^{* *}$ & $0.408^{\mathrm{ns}}$ \\
\hline $\mathrm{CV}(\%)$ & 7.08 & 8.71 & 15.80 & 10.55 & 16.72 \\
\hline
\end{tabular}

Averages followed by the same letters in a column do not differ statistically by Tukey test at $5 \%$ probability. ns - not significant; * significant at $5 \%$; significant at $1 \% ; \mathrm{T} 1=100 \%$ vermicompost, $\mathrm{T} 2=50 \%$ vermicompost $+25 \%$ charred rice husks $+15 \%$ basalt powder $+10 \%$ sand, $\mathrm{T} 3=60 \%$ vermicompost $+15 \%$ charred rice husks $+15 \%$ basalt powder $+10 \%$ sand, $\mathrm{T} 4=60 \%$ vermicompost $+15 \%$ charred rice husks $+10 \%$ basalt powder $+15 \%$ sand, T5 $=$ Plantmax $\mathrm{HA}^{\circledR} ; \mathrm{MS}=$ Mean square, $\mathrm{F}=$ value and significance of the F-test, $\mathrm{CV}=\mathrm{coefficient}$ of variation 
with four to six true leaves, Andriolo, Espindola and Stefanello (2003) found that seedlings with close to five leaves are ready for transplanting. Also, according to the authors, this would allow for a greater number of seedling-production cycles throughout the year.

The results from this study are interesting when based on the complete crop cycle of the lettuce. The period between sowing and harvesting the lettuce was 80 days for seedlings produced with the alternative substrates, 10 days less than for lettuce from seedlings produced using the commercial substrate. This reduction in the lettuce cycle, produced by the use of alternative substrates in the production of seedlings, allows the farmer greater flexibility in production.

\section{CONCLUSIONS}

1. Alternative substrates, based on vermicompost, sterilized sand, rice husks and basalt powder, are efficient in the production of lettuce seedlings, producing better seedlings and in less time than the traditional substrate. The use of these substrates can reduce the crop cycle by up to ten days;

2. The improvement in the quality of seedlings produced with alternative substrates did not affect their development in the field, so that the yield of the lettuce crop was not affected by the substrate used when producing the seedlings.

\section{REFERENCES}

ANDRIOLO, J. L.; ESPINDOLA, M. C. G.; STEFANELLO, M. O. Crescimento e desenvolvimento de plantas de alface provenientes de mudas com diferentes idades fisiológicas. Ciência Rural, v. 33, n. 1, p. 35-40, 2003.

BACKES, M. A. Composto de lixo urbano como substrato para plantas ornamentais. 1988. 80 f. Dissertação (Mestrado em Agronomia) - Universidade Federal do Rio Grande do Sul, Porto Alegre, 1988.

BENINCASA, M. M. P. Análise de crescimento de plantas. Jaboticabal: FUNEP, 1988. 42 p.

CARNEIRO JÚNIOR, A. G.; SENO, S; FERREIRA FILHO, H. F. Avaliação de cinco diferentes substratos para o cultivo de pepino fora do solo. Horticultura Brasileira, v. 18, suplemento, p. 494-495, 2000.

DE BOODT, M.; VERDONCK, O. The physical properties of the substrates in horticulture. Acta Horticulturae, v. 26, p. 37-44, 1972.

FERNANDES, C.; CORÁ, J. E.; BRAZ, L. T. Desempenho de substratos no cultivo do tomateiro do grupo cereja. Horticultura Brasileira, v. 24, n. 1, p. 42-46, 2006.
FERREIRA, D. F. Sisvar - Sistema de análise de variância para dados balanceados. Versão 4.0 (Build 34). Lavras: DEX/ UFLA, 1999. (Software Estatístico)

FILGUEIRA, F. A. R. Novo manual de olericultura: agrotecnologia na produção e comercialização de hortaliças. 2. ed. Viçosa: UFV, 2003. 402p.

LEAL, M. A. A. et al. Utilização de compostos orgânicos como substratos na produção de mudas de hortaliças. Horticultura Brasileira, v. 25, n. 3, p. 392-395, 2007.

LEMAIRE, F. Physical, chemical and biological properties of growing medium. Acta Horticulturae, v. 396, p. 273-284, 1995.

MEDEIROS, D. C. et al. Produção de mudas de alface com biofertilizantes e substratos. Horticultura Brasileira, v. 25, n. 3, p. 433-436, 2007.

MEDEIROS, L.A. M. et al. Crescimento e desenvolvimento da alface (Lactuca sativa L.) conduzida em estufa plástica com fertirrigação em substratos. Ciência Rural, v. 31, n. 2, p. 199-204, 2001.

MENEZES JÚNIOR, F. O. G.; FERNANDES, H. S. Substratos formulados com vermicomposto e comerciais na produção de mudas de couve-flor. Revista Brasileira de Agrociência, v. 4, n. 3, p. 191-196, 1998.

MINAMI, K. Produção de mudas de alta qualidade em horticultura. São Paulo: T. A. Queiroz, 1995. 135 p.

RAIJ, B.; QUAGGIO, J. A. Métodos de análise de solo para fins de fertilidade. Campinas: Instituto Agronômico, 1983. 31 p. (Boletim Técnico, 81).

SCHUMACHER, M. V. et al. Influência do vermicomposto na produção de mudas de Eucalyptus grandis Hill ex Maiden. Ciência Florestal, v. 11, n. 2, p. 121-130, 2001.

SILVA, E. A. et al. Germinação da semente e produção de mudas de alface em diferentes substratos. Semina: Ciências Agrárias, v. 29 , n. 2, p. 245-254, 2008.

SILVA JÚNIOR, A. A.; VISCONTI, A. Recipientes e substratos para a produção de mudas de tomate. Agropecuário Catarinense, v. 4, n. 4, p. 20-23, 1991.

SMIDERLE, O. J. et al. Produção de mudas de alface, pepino e pimentão em substratos combinando areia, solo e plantmax ${ }^{\circledR}$. Horticultura Brasileira, v. 19, n. 3, p. 253-257, 2001.

SOUZA, C. A. S. et al. Crescimento de mudas de gravioleira (Anonna muricata L.) em substrato com superfosfato simples e vermicomposto. Revista Brasileira de Fruticultura, v. 25, n. 3, p. 453-456. 2003.

SOUZA, S. R. et al. Produção de mudas de alface com o uso de substrato preparado com coprólitos de minhoca. Ciência e Agrotecnologia, v. 32, n. 1, p. 115-121, 2008.

VIANA, E. M.; VASCONCELOS, A. C. F. Produção de alface adubada com termofosfato e adubos orgânicos. Revista Ciência Agronômica, v. 39, n. 2, p. 217-224, 2008. 